\title{
The Science of Stem Cell Biobanking: Investing in the Future
}

\author{
GIUSEPPE R. DIAFERIA, 'MARINA CARDANO, ${ }^{1,2}$ MONICA CATTANEO, ${ }^{3}$ CHIARA C. SPINELLI, ${ }^{1,2}$ \\ SARA S. DESSi, ${ }^{1,4}$ PASQUALE DEBLASIO, ${ }^{1,4}$ AND IDA BIUNNO ${ }^{1,3 *}$ \\ 'Integrated Systems Engineering s.r.l., Milan, Italy \\ ${ }^{2}$ Doctorate School of Molecular Medicine, Università degli Studi di Milano, Milan, Italy \\ ${ }^{3}$ IRGB-CNR, Milan, Italy \\ ${ }^{4}$ BioRep s.r.l., Milan, Italy
}

The use of human stem cells in biomedical research projects is increasing steadily and the number of cells that are being derived develops at a remarkable pace. However, stem cells around the world are vastly different in their provenance, programming, and potentials. Furthermore, knowledge on the actual number of cell types, their derivation, availability, and characteristics is rather sparse. Usually, "colleague-supply" avenues constantly furnish cells to laboratories around the world without ensuring their correct identity, characterization, and quality. These parameters are critical if the cells will be eventually used in toxicology studies and drug discovery. Here, we outline some basic principles in establishing a stem cell-specific bank.

J. Cell. Physiol. 227: 14-19, 2012. (c) 20II Wiley Periodicals, Inc.

The explosive interest in generating and intensively studying stem cells is partly due to their emerging potentials in cell-based medicine. Stem cell medicine is a dynamic field rapidly moving from basic research to clinical therapies. Many different stem cell types, to date, have been derived as listed in Table I.

The advent of disease-specific stem cells and stem cell-based therapies necessitates the implementation of accurate procedures, not only to guarantee the continuous supply of each cell line over long periods of time, but also to produce them with an identity and integrity as close as possible to the original cells. Since this bioproduct is becoming very demanding, the workload cannot be handled by small hospital based institutions, but by specialized and certified biobanks. These dedicated infrastructures can actively work towards establishing expedient procedures to promote prompt access to the cell lines and minimize the need for "colleague-supply" routes, which over the years has promoted the widespread use of cross-contaminated and mycoplasma infected cells, jeopardizing the validity of data in the literature (Chatterjee, 2007; NIH, 2007).

Several specialized and specific repository laboratories, called "Stem Cell Bio-Bank" (listed in Table 2), arose in the last decade to meet international healthcare requests.

The International Stem Cell Banking Initiative (ISCBI) committed to create a global network of banks that operate according to unified principles and practices for cell banking, testing, and distribution. To this end, ISCBI has produced a consensus guidance document establishing the best practice in banking and supply of research-grade stem cells applicable to all stems cells including human embryonic (hES) and induced pluripotent (iPS) cells (ISCBI, 2009).

High-throughput molecular technology platforms (“omics") require the use of high-quality bio-samples collected and managed following biosafety requirements and wellstandardized procedures. A strong information technology (IT) structure, a robust tracking system linked to a database, and the application of standard operating procedures (SOPs) ensure the traceability of each cell line deposited from consent through distribution.
The flow-chart in Figure I schematizes the rules that a dedicated stem cell bank should follow within its infrastructure before making their cells a pharmaceutical product.

Steps of the flow-chart will be discussed as specific topic.

\section{Mis-Authentication and Mis-Identification of Stem Cell Lines}

Biomedical researchers that use living cells in culture dishes, must cope with several risks: (i) mis-authentication or misidentification of the cell lines (due to cross-contamination) particularly important for long-term cultures (Drexler et al., 2003); (ii) contamination with bacteria, mycoplasma, viruses, or other fast growing cells of undefined nature; (iii) cytogenetic status. Stringent control of these parameters requires trained personnel, systematic methods of analysis, and rigorous application of well-standardized procedures (SOPs).

When a cell line enters the biobank infrastructure, being it a primary or derived line, the first thing that must be done is its identification through HLA typing or short tandem repeats (STR or microsatellite) analysis (Masters et al., 200I); then create a Master Cell Bank (MCB) consisting of at least 20 ampoules immediately stored at $-196^{\circ} \mathrm{C}$ and a Working Cell Bank (WCB) constituting the distribution line.

\section{All authors share equal merits.}

Contract grant sponsor: NeuroStemcell (European Community's Seventh Framework Programme);

Contract grant number: HEALTH-2008-B-222943.

*Correspondence to: Ida Biunno, IRGB, National Research Council, Via Fantoli I6/I5, 20138 Milan, Italy. E-mail: ida.biunno@itb.cnr.it

Received 26 January 201 I; Accepted 8 March 201 I

Published online in Wiley Online Library (wileyonlinelibrary.com), 16 March 2011 DOI: $10.1002 / j c p .22732$ 
TABLE I. Stem cell classification

\begin{tabular}{ll}
\hline Types of SC & \multicolumn{1}{c}{ Source } \\
\hline Adult & Hematopoietic, mesenchymal, epithelial, endothelial, skin, dental pulp, and cancer \\
Fetal & Hematopoietic, mesenchymal, neural, epithelial, endothelial, skin, and amniotic \\
Embryonic & Morula and inner-cell mass \\
Cord blood & Hematopoietic, mesenchymal, and endothelial \\
Induced pluripotent & Fibroblast, keratinocyte, and blood progenitor \\
\hline
\end{tabular}

The ethical committee approval from the donor's institution must be included in the IT database, certifying that all legal and ethical requirements have been met and proper informed consent has been signed from the donor. Furthermore, this database must contain all the information regarding the cell lines currently available and ethically approved for distribution. Although each institute has its own database, several efforts have been made to establish a centralized registry of public available stem cells (Table 3 ). For researchers seeking to work with stem cell lines, part of the problem is to find them; a good stem cell investment could be to create a centralized registry containing each stem cell background and their obtainability.

\section{Sterility QC Testing of Stem Cell Lines for Basic and} Clinical Research

Ensuring sterility of MCB and WCB lines is fundamental, since microbial contamination can change the characteristics of the cells without obvious cytopathic effects, but the use of such culture can damage the quality of research and/or expose researchers to infectious agents. However, cells with established contamination can be used in several research applications, but must be handled separately from the other cultures.

The current testing standard for mycoplasma contamination simply relies on bacterial growth in nutrient media (broth and agar) (Barbara et al., 2008) for 3-weeks (United States Food and Drug Administration, 2008a), while polymerase chain reaction (PCR)-based mycoplasma detection methods expedite the results (Venor GeM kit, Minerva Biolabs, Berlin, Germany).

Bacteria borne-disease contaminations can be detected by seeding cell culture medium on bacteriology plates containing selective growth medium specific for aerobic or anaerobic contaminants. After different incubation times (from 7 to 20 days), the plates are inspected for bacteria growth. The $16 \mathrm{~S}$ DNA amplification assay can assess the nature of the putative bacterial colony (Gonzales and McDonough, 1998).

Clinically significant transmissible infections which need to be tested before releasing the cells are: (i) parasitic protozoa (malaria, Chagas'disease, Leishmania, Plasmodium falciparum, etc.); (ii) bacteria borne-diseases such as Chlamydia trachomatis
(CT), Neisseria gonorrhoeae (GC) and Mycobacteria tuberculosis (MTB); (iii) viral borne-diseases such as human immunodeficiency virus (HIV), hepatitis $\mathrm{C}$ virus (HCV), hepatitis $B$ virus (HBV), human papilloma virus (HPV), parvovirus, and the prion variant VCJD (ISCBI, 2009). Nucleic acids amplification technology (NAT) reflects a rapid means of detection and monitoring of the infective agents as well as assessing the clinical disease-associated with the infection (Benjamin, 200I). NAT stations have been developed by Roche (Mannheim, Germany), Abbott Diagnostics (Delkenheim, Germany), Siemens Medical Solution (Forchheim, Germany), BioMérieux (Marcy l'Étoile, France), Becton and Dickinson (San Jose, CA, USA), Gen-Probe (Biermann GmbH, Bad Nauheim, Germany). These station are based on nucleic acids extraction protocols (SOPs) and a real-time PCR instrument which enhances the accuracy (highly specific detection and quantification of extremely low levels of disease agents), rapidity, and ability to quantitate viral target sequences (Logna et al., 2009). In order to decrease human errors, robotized stations can be used.

Currently, there are no available validated sensitive detection methods for prions and transmissible spongiform encephalopathies (TSEs) agents. However, a constant traceability of the geographic origin of donor animals must be included in the database avoiding products derived from countries classified as geographical bovine spongiform encephalopathy (BSE)-risk I and II (Heim and Mumford, 2005).

\section{Genetic stability}

Extensive in vitro culturing over large periods can also lead to cellular senescence, as well as genetic and epigenetic changes. Spectral karyotyping (SKY), used to detect gross chromosomal alterations, must be performed regularly to ensure chromosomal stability as a function of culturing, freezing, and thawing. Even if human stem cell lines have shown an overall preservation of euploidy during long-term culturing (Hoffman and Carpenter, 2005), recurrent abnormalities have been reported (Buzzard et al., 2004; Lefort et al., 2008; Närvä et al., 2010). Studies on mouse stem cell lines have in fact described that many chromosomal aberrations did occur during in vitro culturing and genetic engineering procedures, but such genetic

TABLE 2. Stem cell banks

\begin{tabular}{|c|c|c|}
\hline Public or no-profit stem cell bank & Affiliation & Link \\
\hline UK Stem Cell Bank & UK governance & http://www.ukstemcellbank.org.uk \\
\hline $\begin{array}{l}\text { National Stem Cell Bank-Banco-Nacional de } \\
\text { Lineas Celulares (BNLC) } \\
\text { Valencia Stem Cell Bank-BNLC }\end{array}$ & Spanish governance & $\begin{array}{l}\text { http://www.isciii.es/htdocs/terapia/terapia_ } \\
\text { bancocelular.jsp }\end{array}$ \\
\hline National Centre for Cell Science-Cell Repository & Indian governance & http://www.nccs.res.in \\
\hline WiCell International Stem Cell Bank & University of Wisconsin & http://www.wicell.org \\
\hline Australian Stem Cell Bank & Australian governance & http://www.ascb.com.au \\
\hline Singapore Stem Cell Bank & $\begin{array}{l}\text { Agency for Science, Technology } \\
\text { and Research (A*STAR) }\end{array}$ & http://www.sscc.a-star.edu.sg/stemCellBank.php \\
\hline Korean Stem Cell Bank & Korean governance & http://kscb.co.kr/eng \\
\hline Taiwan Stem Cell Bank & National Science Council & http://www.tscb.bcrc.firdi.org.tw \\
\hline Umass Human Stem Cell Bank \& Registry & University of Massachusetts Medical School & http://www.umassmed.edu/mhscb/index.aspx \\
\hline $\begin{array}{l}\text { Rutgers University Cell and DNA repository } \\
\text { Coriell Institute }\end{array}$ & $\begin{array}{l}\text { Rutgers Unniversity } \\
\text { Private no-profit }\end{array}$ & $\begin{array}{l}\text { http://www.rucdr.org/ } \\
\text { www.coriell.org }\end{array}$ \\
\hline
\end{tabular}




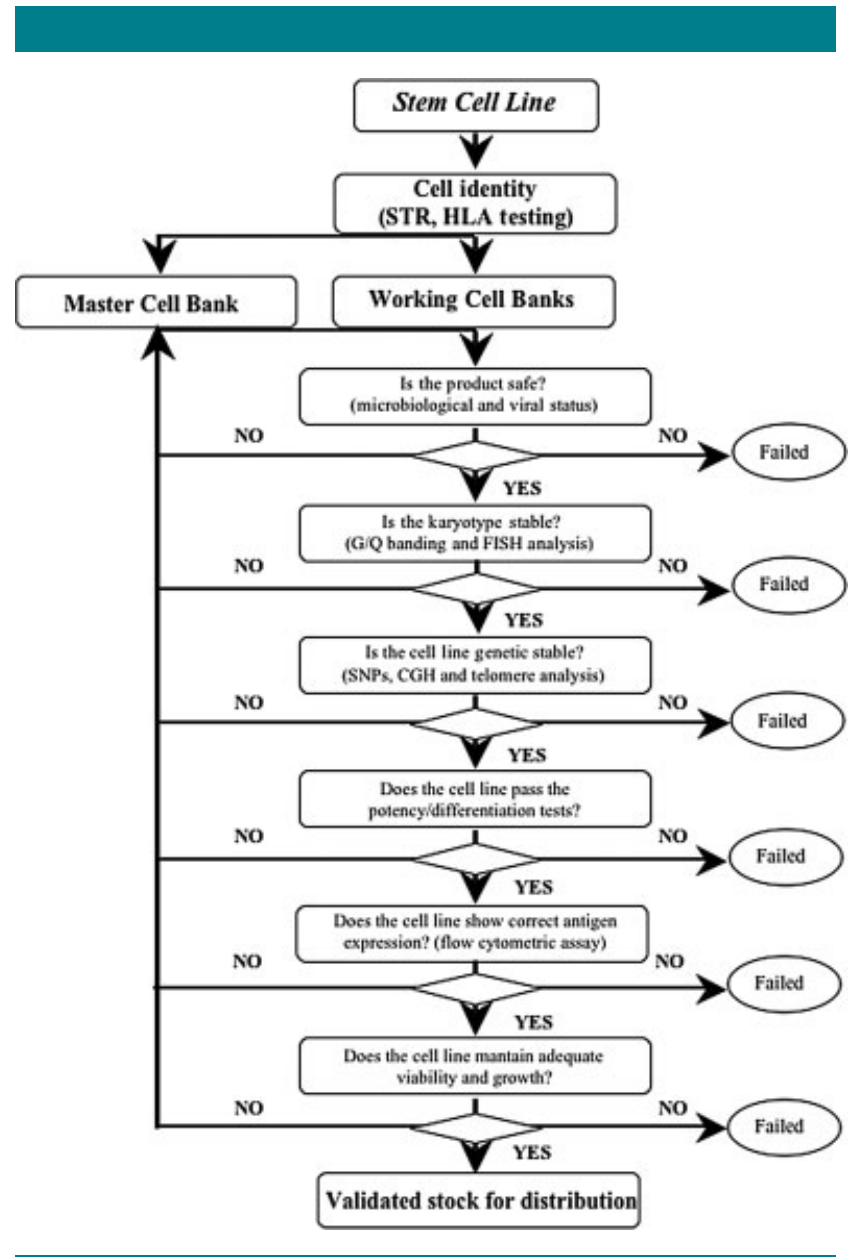

Fig. I. Rules of a stem cell biobank.

changes did not affect the overall biological properties of the cells (Diaferia et al., 20I I). Notably, propensity to karyotype instability can vary between different lines, regardless of the culturing conditions, duration, or splitting techniques; it is therefore encouraged to regularly perform regular highresolution molecular and cytogenetic studies to identify chromosomal mosaicisms that might lead to genetic susceptibility to disease or transformation.

Small genomic variations and submicroscopic DNA alterations that can potentially affect cell phenotype, may be evaluated by performing comparative genomic hybridisation $(\mathrm{CGH})$, where the use of fluorescent dyes that bind to specific regions of the chromosomes allows the acquisition of full digital colored images of the chromosomes. DNA gain or loss can be identified as well as cell characteristic patterns including mutations at chromosomal or sub-chromosomal levels (Stephenson et al., 2010). CGH is a powerful molecular genetic tool to screen genomes for chromosomal imbalances but has some limitations: the technique detects neither balanced chromosomal translocations or inversion nor small interstitial deletions. Other methods such as "SKY" and multiple single nucleotide polymorphism (SNP) analysis could provide useful and specific information about copy number changes (gains/ losses) and/or nucleotide variation in the DNA content (ISCBI, 2009).

However, despite these standardized definitions and criteria that aid the reproducibility of stem cell cultures, little is known about their long-term safety, stability, and differentiated derivates.

Furthermore, the extension in telomere length that occurs with the increasing number of stem cells passages and the reduced rate of spontaneous differentiation, suggest that a standardized and validated procedure for characterizing stem cells at a specific passage number is essential for their potential use in therapeutic applications. Thus, further analysis can be required to determine whether telomere length stabilizes or shortens during cell culture. The PCR based telomeric repeat amplification protocol (TRAP) assay can be used to detect telomerase activity and the terminal restriction fragment (TRF) analysis to evaluate the length of telomere (Herbert et al., 2003).

\section{Biological attributes to stem cells: regulations of stem cell-based products}

The self-renewal and the capacity to differentiate into multiple cell types (pluripotency) make stem cells attractive candidates for the functional regeneration of damaged tissues. Once assured the sterility from microbial, fungal, endotoxin, mycoplasma, and viral contamination, each cell line must be controlled for its "potency;" the US Food and Drug Administration (FDA) regulates clinical trials to ensure that subjects enrolled in a study involving stem cell-based products are not exposed to significant and unreasonable risks (United States Food and Drug Administration, 2008b). The only way to attest the physical nature of stem cells is to evaluate their potency as the capacities to self-renew and differentiate in appropriate conditions. Obviously, substantial differences in term of potency exist among the various types of stem cells: the pluripotency characterizes only embryonic stem cells (ESCs) that have the virtual ability to generate any adult cell type, while the embryonic germ cells (EGCs) can ultimately produce only gametes. The limitless self-renewal potential and the capacity to give rise to all differentiated cell types make ESCs able to spontaneously form teratoma-like masses after injection into immunodeficient mice (Thomson et al., 1998; Brivanlou et al., 2003). Biobanks should verify that this characteristic is preserved in their cell collections both in the MCB and in the WCB. Alternatively, the capacities of ESCs to form embryoid bodies or to differentiate under specific conditions in vitro could also be evaluated (ISCBI, 2009).

Since these biobanks are stem cell dedicated, specific tests should be set up to verify surface antigen marker profiles: SSEAI negative or very low, SSEA-3 positive, SSEA-4 positive, TRAI -60 positive, and TRA-I -8I positive. A more complete analysis should include the evaluation of the expression of six other genes particularly linked to the ESC phenotype: Nanog, Oct 4, DNMT 3B, TDGF, GABRB3, and GDF3 (International Stem Cell Initiative, 2007).

TABLE 3. Stem cell registry

\begin{tabular}{lll}
\hline Registry & & Funding \\
\hline European hESC Registry & EU & Link \\
StemDB & EU & http://www.hescreg.eu/ \\
US NIH & US & http://grants.nih.gov/stem_cells/registry/current.htm \\
International Stem Cell Registry & Massachusetts Life Sciences Center & http://www.umassmed.edu/iscr/index.aspx \\
\hline
\end{tabular}


Differently from ESCs, the fetal or adult stem cells are capable of producing a limited pool of different mature cell types. For example, human mesenchymal stem cells (hMSCs) are adult stem cells efficiently isolable from bone marrow, adipose tissues, umbilical cords, fresh cord blood, and amniotic membranes (Kern et al., 2006; Alviano et al., 2007) that retain the capacity to differentiate in numerous, but limited cell types (Motaln et al., 20l0).

Here are listed some examples of pre-requisites necessary to validate hMSCs (Dominici et al., 2006):

(i) ability to adhere to plastic when maintained in tissue culture flasks;

(ii) expression (measured by flow cytometry) of hMSCspecific antigen markers (CDI05, CD73, and CD90) in $>95 \%$ cell population and the positivity for CD45, CD34, CDI 4 or CDI Ib, CD79a or CDI9, and HLA class II only in $<2 \%$ of cells (Rubio et al., 2005; Wang et al., 2005; Kogler et al., 2006);

(iii) in vitro tri-lineage differentiation potential into osteoblasts (positive for Alizarin red or von Kossa staining), adipocytes (stained by Oil red $\mathrm{O}$ ), and chondroblasts (stained with Alcian blue or immunopositive for collagen type II).

Neural stem cells, instead, are resident in the developing and adult mammalian central nervous system (Temple, 200I) and they can grow in vitro as neurospheres or adherent cultures (Kokovay et al., 2008), maintaining the capacity to differentiate in all three neural types: astrocytes, oligodendrocytes, and neurons (Pollard et al., 2006). Therefore, they should be tested for:

(i) expression of undifferentiation markers nestin, RC2, SOX2, BLBP, GLAST, PAX6, and CD44 (Conti and Cattaneo, 20I0);

(ii) number of GFAP immunopositive astrocytes, 04 immunopositive oligodendrocytes, and $\beta$ III-tubulin positive neurons generated under appropriate culture conditions.

\section{Biological attributes to induced pluripotent stem cells (iPS)}

The advent of iPS cells, generated by reprogramming of nonpluripotent, differentiated, adult somatic cells, has endured interest in their possible use to generate autologous cell products (Stadtfeld and Hochedlinger, 2010). However, the generation of these cells presents novel risks and additional safety issues, which must be addressed.

Multiparametric testing must be used to characterize these cellular products:

(i) morphologic evaluation compared to ES;

(ii) detection of phenotype-specific cell surface antigens compare to ES;

(iii) assess unique and cell-specific biochemical markers;

(iv) pluripotency parameters;

(v) silence exogenous factors used for reprogramming;

(vi) loss of somatic cell-specific markers;

(vii) expression of functional telomerase;

(viii) $\mathrm{X}$ chromosome reactivation (in female cells).

Morphologically and biochemically, iPS cells must behave as close as possible to ES cells (Yu et al., 2007, 2009; Lowry et al., 2008). At the molecular level, iPS cells must display geneexpression profiles that are undistinguishable from ES cells, including the reactivation of the appropriate stage-specific embryonic antigens (e.g., alkaline phosphatase and stage- specific embryonic antigen I SSEA-I in mouse, SSEA-3, SSEA-4 and the tumor recognition antigens TRA-I-60, and TRA-I-8I in human) and the endogenous genes essential for pluripotency and self-renewal (e.g., Sox2, Oct4, and Nanog). They must also be epigenetically similar to ES cells by expressing the key pluripotent genes Nanog and Oct4, rearranging chromatin structure to be transcriptionally permissive for pluripotent genes and inactive for developmental genes (Koche et al., 20 I I). Functionally, iPS cells must be able to differentiate into lineages from all three embryonic germ layers as demonstrated through the teratoma formation test in immunodeficient mice for human cells and contribution to chimera production following blastocyst injection for murine cell.

Table 4 summarizes the quality control criteria and techniques used to characterize iPS compared to ESCs.

Integrative genome-wide approaches, such as the geneexpression microarray, chromatin immunoprecipitation based microarray (ChIP-chip), chromatin immunoprecipitation followed by massive parallel sequencing (ChIP-seq), and RNA/ DNA sequencing platforms could offer opportunities to monitor the pluripotency, reprogramming, and DNA damage response of iPS cells.

\section{Future efforts to ensure patient's safety: detection of biomarkers for undifferentiated stem cells}

Most of the tests described so far aim to target the cell type within a given stem cell-based product having the desired characteristics and attributes. However, it would be just as important to develop a panel of analytical tests ("biomarkers"), which would detect cellular impurities: a cell population with unwanted features (Bhatt et al., 2010). Those biomarkers should detect permanently undifferentiated stem cells linked to tumorigenesis ("cancer stem cells") that if settle in a favorable microenvironment would generate a cancer (LaBarge, 20I0).

Another important development in stem cell therapeutics would be to identify biomarkers, which could anticipate the effectives of the cell therapy.

Studies by Long and Bulte (2009) reported the development of new animal disease-specific model systems, which, in addition to sensitive and non-invasive imaging methodologies, can monitor cell migration and ectopic tissue formation after stem cell administration.

\section{Stem cells cryopreservation}

Currently, all cell lines are cryopreserved by slow cooling or vitrification followed by rapid thawing. The extremely rapid cooling rates employed to achieve vitrification require direct immersion of open-pulled straws containing microliter quantities of cell suspension into liquid nitrogen. While suitable for the lab bench from a safety and regulatory perspective, this method conflicts with the therapeutic requirement for a sterile product and imposes severe difficulties for scale-up.

While vitrification does not require any cryoprotective agent (CPA), the conventional slow-cooling method needs special CPA to reduce ice crystal formation preserving cell membrane integrity (Hunt and Timmons, 2007). One of the most widely used CPA for freezing cultured cells is dimethylsulfoxide (DMSO) in concentration of $10 / 20 \%$ in addition to animal proteins. Beside the risk of using animal derivates as carrier of contaminants, DMSO can also cause unexpected changes in cell fate. Several reports have underlined the diminished pluripotency capacity of hESC exposed to DMSO (Adler et al., 2006; Katkov et al., 2006) and the inhibition of throphoblast stem cell differentiation by induction of a quiescent state in a dose-dependent manner (Sahgal et al., 2005). These effects might be due to changes in methylation and acetylation profiles, known to control mammalian development and cellular differentiation. DMSO likely affects these epigenetic changes by 


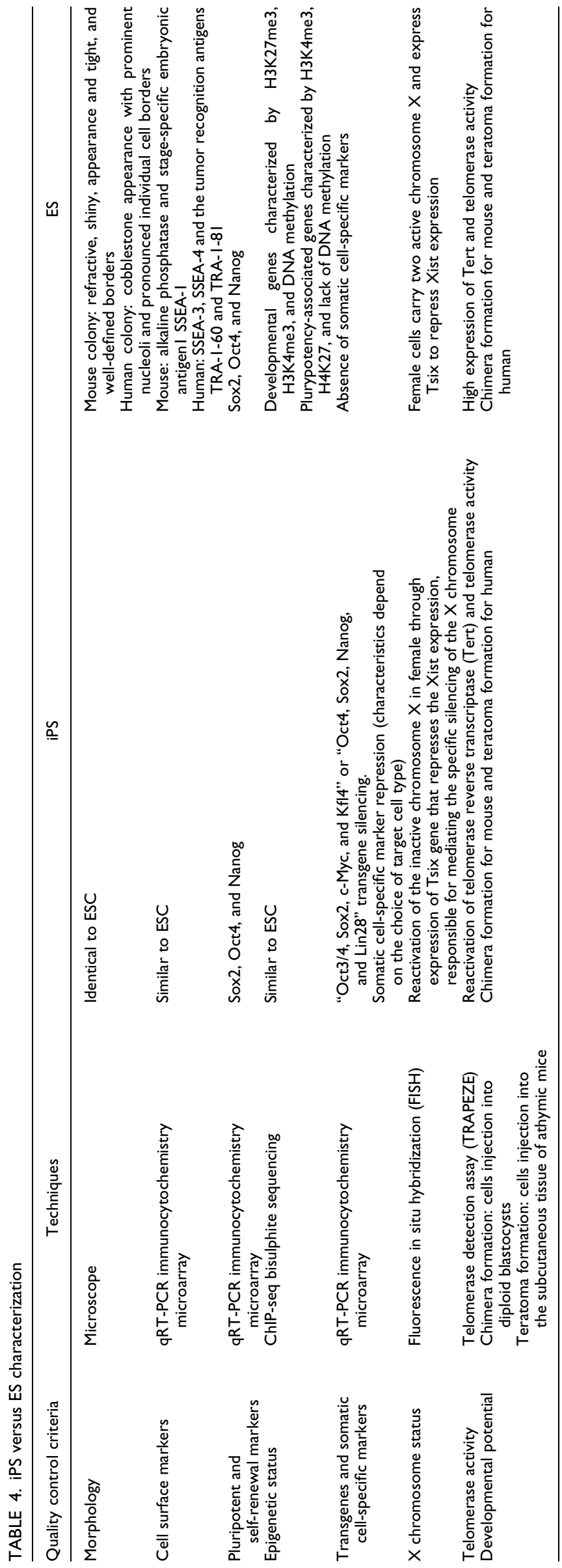

acting on the three DNA methyltransferases (Dnmts) and on five histone modification enzymes (Iwatani et al., 2006).

These effects may have an impact on the value of SC banks and the effective therapeutic application of SCs in regenerative medicine or for pharmaceutical drug screening. In order to use stem cells in cells therapy, several studies aim to develop a nontoxic CPA, DMSO, and protein-free. All cell line batches stored in liquid nitrogen must be assessed for recovery and viability after cryopreservation, performing vitality and death tests after 0 and $24 \mathrm{hr}$ from thawing by trypan blue exclusion and FACS counting. Sentinel cell lines must be tested periodically for viability to confirm the integrity of liquid nitrogen storage longterm.

\section{Administrative requirements}

The science of stem cell banking must also meet all the ethical and legal requirements to be able to demonstrate that has followed all the appropriate regulatory standards. Documentation of banking procedures is vital and it should include: (i) informed consent from the donor for the procurement of the tissue and derivation of the cell lines; (ii) all relevant data from quality controls and characterization; (iii) a material safety datasheet on hazards associated with the cells; (iv) a material transfer agreement (MTA) to guarantee ownership and avoid third party distribution; and (v) all necessary declarations and labels to meet local import regulations (ISCBI, 2009).

For these reasons a stem cell bank should be accredited or authorized by appropriate authorities for the purpose of their activities and should have an independent and transparent governance structure, which reviews the ethical and legal requirements. Even with such structured organization the terms of the informed consent, national laws on stem cell research and the continuous improvement in stem cell culture protocols may complicate the establishment of one uniform set of ethics and standards by which cells should be handled and used (Healy et al., 2008; Crook et al., 20 I0). The review process of these dynamic landscapes, spanning from ethic to law, science and management, needs to be continuously performed and made available to the international scientific community to improve the generation of high-quality biomaterial and facilitate its accessibility.

\section{Discussion}

Creating standards for the characterizing of all stem cell types is a big challenge. Pluripotent stem cells tend to be genetically unstable, particularly if less than optimal culture techniques are used. Hence, for many labs, the time and money needed to make high-quality pluripotent stem cells available to the broad research community are beyond their means.

Academics sharing is a nice idea, but unrealistic given the subject matter, times, and law. University administrations will put strings on stem cell distributions by their scientists due to intellectual property rights and potential source of revenue.

On the other hand, National Stem Cell Bank funded by the government and making high-quality cells available to all researchers at reasonable cost, would actually be quite ideal and desirable.

The exponential generation and use of disease- and patientspecific stem cell lines will require proper storage facilities to handle high-quality and precious material. Even if the number of cell lines grow, the number of banks will probably level off in the near future due to extensive quality controls and excellence of the banking effort in the long-term. That's especially true for ESCs and ultimately for iPS.

While the establishment of iPS cell lines is conceptually and technically simple, direct reprogramming is a slow and inefficient process consisting of largely unknown events. A 
single reprogramming experiment usually generates multiple iPS cell lines that are not always identical. Each individual iPS cell line needs to be fully characterized to ensure safety and pluripotency capacity. Several variables must be considered in order to reproducibly obtain iPS, which include: (i) the choice of factors used to reprogram cells; (ii) the methods used to deliver these factors; (iii) the choice of target cell type; (iv) the parameters of factor expression, such as timing and levels; (v) the culture conditions used to derive iPSCs; (vi) the methods of identifying; (vii) characterizing reprogrammed cells.

The fact that iPS can be maintained in vitro indefinitely makes the establishment of cell banking facilities attractive and distribution of high-quality iPS lines to interested parties would facilities further development of clinical regenerative therapies and toxicological tests.

We should not forget that the biggest obstacle in every aspect of stem cell study is still the biology itself: the biology of the cells and of the diseases. Because the biology is so tough everything else should be made accessible.

\section{Acknowledgments}

We acknowledge the support of NeuroStemcell (European Community's Seventh Framework Programme grant agreement no. HEALTH-2008-B-222943). We also are gratefu to Marble Arch working Group on International Biobanking and the European Middle Eastern and African Society for Biopreservation and Biobanking (ESSB) as knowledge provider.

\section{Literature Cited}

Adler S, Pellizzer C, Paparella M, Hartung T, Bremer S. 2006. The effects of solvents on embryonic stem cell differentiation. Toxicol In Vitro 20:265-27I.

Alviano F, Fossati V, Marchionni C, Arpinati M, Bonsi L, Franchina M, Lanzoni G, Cantoni S, Cavallini C, Bianchi F, Tazzari PL, Pasquinelli G, Foroni L, Ventura C, Grossi A, Bagnara GP. 2007. Term amniotic membrane is a high throughput source for multipotent mesenchymal stem cells with the ability to differentiate into endothelial cells in vitro. BMC Dev Biol I:II.

Barbara JAJ, Regan FAM, Contreras MC. 2008. Transfusion microbiology. Cambridge, UK Cambridge University Press. 390 pp.

Benjamin RJ. 200I. Nucleic acid testing: Update and applications. Semin Hematol 38:1 I-16. Review.

Bhatt AN, Mathur R, Farooque A, Verma A, Dwarakanath BS. 2010. Cancer biomarkerscurrent perspectives. Indian J Med Res 132:129-149.

Brivanlou AH, Gage FH, Jaenisch R, Jessell T, Melton D, Rossant J. 2003. Stem cells. Setting standards for human embryonic stem cells. Science 300:9/3-916.

Buzzard JJ, Gough NM, Crook JM, Colman A. 2004. Karyotype of human ES cells during extended culture. Nat Biotechnol 22:38I-382.

Chatterjee R. 2007. Cell biology: Cases of mistaken identity. Science 315:928-931.

Conti L, Cattaneo E. 2010. Neural stem cell systems: Physiological players or in vitro entities? Nat Rev Neurosci II:176-187.

Crook JM, Hei D, Stacey G. 20I0. The International Stem Cell Banking Initiative (ISCBI): Raising standards to bank on. In Vitro Cell Dev Biol Anim 46:169-172.

Diaferia GR, Conti L, Redaelli S, Cattaneo M, Mutti C, DeBlasio P, Dalprà L, Cattaneo E, Biunno I. 20II. Systematic chromosomal analysis of cultured mouse neural stem cell lines. Stem Cell Dev Mar 12. [Epub ahead of print]

Dominici M, LeBlanc K, Mueller I, Slaper-Cortenbach I, Marini F, Krause D, Deans R, Keating A, Prockop Dj, Horwitz E. 2006. Minimal criteria for defining multipotent mesenchyma stromal cells. The International Society for Cellular Therapy Position Statement. Cytotherapy 8:315-317.

Drexler HG, Dirks WG, Matsuo Y, MacLeod RA. 2003. False leukemia-lymphoma cell lines: An update on over 500 cell lines. Leukemia 17:416-426.

Gonzales F, McDonough S. 1998. Applications of transcription-mediated amplification to quantification of gene sequences. In: Ferre F, editor. Gene amplification. Boston: Birkhauser. pP 189-204.

Healy LE, Ludwig TE, Choo A. 2008. International banking: Checks, deposits, and withdrawals. Cell Stem Cell 2:305-306.

Heim D, Mumford E. 2005. The future of BSE from the global perspective. J Meat Sci 70:555562 .

Herbert BS, Shay JW, Wright WE. 2003. Analysis of telomeres and telomerase. In: Bonifacino JS, Dasso M, Lippincott-Schwartz J, Harford JB, Yamada KM, editors. Current Protocols in Cell Biology (online). Hoboken, NJ: Wiley and Sons. PP 18.6.I-18.6.20.

Hoffman LM, Carpenter MK. 2005. Human embryonic stem cell stability. Stem Cell Rev 1:139-144. Review.

Hunt C], Timmons PM. 2007. Cryopreservation of human embryonic stem cell lines. Methods Mol Biol 368:26I-270.
International Stem Cell Initiative, Adewumi O, Aflatoonian B, Ahrlund-Richter L, Amit M, Andrews PW, Beighton G, Bello PA, Benvenisty N, Berry LS, Bevan S, Blum B, Brooking!. Chen KG, Choo AB, Churchill GA, Corbel M, Damjanov I, Draper JS, Dvorak P, Emanuelsson K, Fleck RA, Ford A, Gertow K, Gertsenstein M, Gokhale PJ, Hamilton RS, Hampl A, Healy LE, Hovatta O, Hyllner J, Imreh MP, Itskovitz-Eldor J, Jackson J, Johnson JL, Jones M, Kee K, King BL, Knowles BB, Lako M, Lebrin F, Mallon BS, Manning D, Mayshar Y, McKay RD, Michalska AE, Mikkola M, Mileikovsky M, Minger SL, Moore HD, Mummery CL Nagy A, Nakatsuji N, O'Brien CM, Oh SK, Olsson C, Otonkoski T, Park KY, Passier R, Pate H, Patel M, Pedersen R, Pera MF, Piekarczyk MS, Pera RA, Reubinoff BE, Robins AJ, Rossant J, Rugg-Gunn P, Schulz TC, Semb H, Sherrer ES, Siemen H, Stacey GN, Stojkovic M,

Suemori H, Szatkiewicz J, Turetsky T, Tuuri T, van den Brink S, Vintersten K, Vuoristo S, Ward D, Weaver TA, Young LA, Zhang W, 2007. Characterization of human embryonic stem cell lines by the International Stem Cell Initiative. Nat Biotechnol 25:803 816 .

ISCBI (International Stem Cell Banking Initiative). 2009. Consensus guidance for banking and supply of human embryonic stem cell lines for research purposes. Stem Cell Rev Rep 5:30I-3I4.

Iwatani M, Ikegami K, Kremenska Y, Hattori N, Tanaka S, Yagi S, Shiota K. 2006. Dimethyl sulfoxide has an impact on epigenetic profile in mouse embryoid body. Stem Cells 24:25492556

Katkov II, Kim MS, Bajpai R, Altman YS, Mercola M, Loring JF, Terskikh AV, Snyder EY, Levine F. 2006. Cryopreservation by slow cooling with DMSO diminished production of Oct-4 pluripotency marker in human embryonic stem cells. Cryobiology 53:194-205.

Kern S, Eichler H, Stoeve J, Kluter H, Bieback K. 2006. Comparative analysis of mesenchyma stem cells from bone marrow, umbilical cord blood, or adipose tissue. Stem Cells 24:1294 |30|

Koche RP, Smith ZD, Adli M, Gu H, Ku M, Gnirke A, Bernstein BE, Meissner A. 2011. Reprogramming factor expression initiates widespread targeted chromatin remodeling. Cell Stem Cell 8:96-105.

Kogler G, Radke FT, Lefort A, Sensken S, Fischer J, Sorg RV, Wernet P. 2006. Cytokine production and hematopoiesis supporting activity of cord blood-derived unrestricted somatic stem cells. Exp Hematol 33:573-583.

Kokovay E, Shen Q, Temple S. 2008. The incredible elastic brain: How neural stem cells expand our minds. Neuron 60:420-429.

LaBarge MA. 2010. The difficulty of targeting cancer stem cell niches. Clin Cancer Res $16: 3121-3129$

Lefort N, Feyeux M, Bas C, Féraud O, Bennaceur-Griscelli A, Tachdjian G, Peschanski M, Perrier AL. 2008. Human embryonic stem cells reveal recurrent genomic instability at 20q I.2I. Nat Biotechnol 26:1364-1366

Logna J, Edwards K, Saunders N. 2009. Real Time PCR: Current technology and applications. Norfolk, UK: Caister Academic Press. 284 pp.

Long CM, Bulte JW. 2009. In vivo tracking of cellular therapeutics using magnetic resonance imaging. Expert Opin Biol Ther 9:293-306.

Lowry WE, Richter L, Yachechko R, Pyle AD, Tchieu J, Sridharan R, Clark AT, Plath K. 2008 Generation of human induced pluripotent stem cells from dermal fibroblasts. Proc Nat Acad Sci USA 105:2883-2888.

Masters JR, Thomson JA, Daly-Burns B, Reid YA, Dirks WG, Packer P, Toji LH, Ohno T, Tanabe H, Arlett CF, et al. 200I. Short tandem repeat profiling provides an international reference standard for human cell lines. Proc Natl Acad Sci USA 98:80I2-80I7.

Motaln H, Schichor C, Lah TT. 2010. Human mesenchymal stem cells and their use in cellbased therapies. Cancer I16:2519-2530.

Närvä E, Autio R, Rahkonen N, Kong L, Harrison N, Kitsberg D, Borghese L, Itskovitz-Eldor J Rasool O, Dvorak P, Hovatta O, Otonkoski T, Tuuri T, Cui W, Brüstle O, Baker D, Maltby E, Moore HD, Benvenisty N, Andrews PW, Yli-Harja O, Lahesmaa R. 20I0. Highresolution DNA analysis of human embryonic stem cell lines reveals culture-induced copy number changes and loss of heterozygosity. Nat Biotechnol 28:37I-377.

NIH. 2007. Notice regarding authentication of cultured cell lines, NOTod-08-017, Nov 28 , $\mathrm{NiH}$

Pollard SM, Conti L, Sun Y, Goffredo D, Smith A. 2006. Adherent neural stem (NS) cells from fetal and adult forebrain. Cereb Cortex I6:il I2-il20.

Rubio D, Garcia-Castro J, Martin MC, de la Fuente R, Cigudosa JC, Lloyd AC, Bernad A. 2005 Spontaneous human adult stem cell transformation. Cancer Res 65:3035-3039.

Sahgal N, Canham LN, Konno T, Wolfe MW, Soares MJ. 2005. Modulation of trophoblast stem cell and giant cell phenotypes: Analyses using the Rcho-I cell model. Differentiation 73:452-462.

Stadtfeld M, Hochedlinger K. 2010. Induced pluripotency: History, mechanisms, and applications. Genes Dev 24:2239-2263.

Stephenson E, Ogilvie CM, Patel H, Cornwell G, Jacquet L, Kadeva N, Braude P, Ilic D. 2010. Safety paradigm: Genetic evaluation of therapeutic grade human embryonic stem cells. J $R$ Soc Interface 7:S677-S688.

Temple S. 200I. The development of neural stem cells. Nature 4|4:1 I2-117.

Thomson JA, Itskovitz-Eldor J, Shapiro SS, Waknitz MA, Swiergiel J], Marshall VS, Jones JM. 1998. Embryonic stem cell lines derived from human blastocysts. Science 282: | | 45-1 | 47 . Erratum in: Science 282:1827.

United States Food and Drug Administration. 2008a. Validation of growth-based rapid microbiological methods for sterility testing of cellular and gene therapy products. Rockville: Guidance for Industry.

United States Food and Drug Administration. 2008b. Potency tests for cellular and gene therapy products. Rockville: Guidance for Industry.

Wang Y, Huso DL, Harrington J, Kellner J, Jeong DK, Turney J, McNiece IK. 2005. Outgrowth of a transformed cell population derived from normal human BM mesenchymal stem cell culture. Cytotherapy 7:509-519.

Yu J, Vodyanik MA, Smuga-Otto K, Antosiewicz-Bourget J, Frane JL, Tian S, Nie J, Jonsdottir GA, Ruotti V, Stewart R, Slukvin II, Thomson JA. 2007. Induced pluripotent stem cell lines derived from human somatic cells. Science 318:1917-1920.

Yu J, Hu K, Smuga-Otto K, Tian S, Stewart R, Slukvin II, Thomson JA. 2009. Human induced pluripotent stem cells free of vector and transgene sequences. Science 324 797-801. 